\title{
KEYNOTE ADDRESS:
}

\section{COMPETITIVENESS IN MANUFACTURING - PUTTING ALL THE ELEMENTS TOGETHER}

\author{
J. PARNABY CBE, FEng, DSc, DTech, CEng \\ Managing Director \\ Lucas Applied Technology Ltd \\ Lucas Industries plc, PO Box 52 \\ Shirley, Solihull \\ West Midlands B90 4JJ
}

\section{$\underline{\text { SYNOPSIS }}$}

The creation of a competitive manufacturing business is a multifaceted activity in which all the elements required must be integrated very professionally.

From the top level of the business in which there is a requirement to re-engineer the core processes to make them world class to the bottom-up view of manufacturing cell design, there is a need for total professionalism.

If a manufacturing business is envisaged as a set of cells this helps to clarify the systematic and detailed engineering procedures required to be applied by the manufacturing systems engineer.

A cell focus enables a structured and practical approach combining selective automation with methodologies for design and operation by cross functional design teams to meet best practice measures of performance.

It is of critical importance that the practical engineer and technical manager are fully conversant with the systems approach ie the way in which mutually supportive elements such as total productive maintenance, materials flow control, continuous improvement, levelled scheduling, automated assembly and testing and the tools for quality management and process capability enhancement can be utilised to create truly lean world class manufacturing.

This presentation summarises the process detailed above and its application in Lucas Industries and elsewhere. 